\title{
ANSERJ
}

Vol. 12, No. S1

Autumn / automne 2021

pp. $31-45$

Canadian Journal of Nonprofit and Social Economy Research

Revue canadienne de recherche sur les OSBL et l'économie sociale

\section{COVID-19 and the Restructuring of Collective Solidarity: The Case of Volunteer Activity in Québec}

\author{
Diane Alalouf-Hall \& David Grant-Poitras \\ Université du Québec à Montréal and \\ Canadian Philanthropy Partnership Research Network
}

\begin{abstract}
Drawing on a combination of survey data, semi-structured interviews, and document analysis, this article explores the main forms of restructuring that have taken place within Québec's voluntary sector in response to the COVID-19 pandemic. It centres on three main shifts: the designation of certain voluntary activities as "essential services" by politicians; the implementation of new approaches to soliciting, matching, and retaining volunteers; and the institutionalization of a new health-centric rationality within the supervision of volunteer work. The article concludes by calling for recognition, in theory and practice, of the essential role that volunteering plays with regard to socio-territorial resilience.
\end{abstract}

\section{RÉSUMÉ}

Mobilisant les données d'un travail de veille portant sur l'impact de la pandémie de COVID-19 sur le secteur de bienfaisance au Québec, cet article explore les principales restructurations qui se sont opérées au sein du secteur bénévole. Nos enquêtes nous ont permis d'en dégager trois : la qualification, par le politique, de certaines activités bénévoles en " services essentiels » ; la mise en œuvre de nouvelles approches en matière de sollicitation, de jumelage et de rétention des bénévoles ; l'obligation pour les organismes d'encadrer le travail des bénévoles en fonction d'une « rationalité sanitaire ». L'article se clore avec une discussion où nous appelons à reconnaître, tant en théorie qu'en pratique, le rôle incontournable du bénévolat en matière de résilience socio-territoriale.

Keywords / Mots clés : Volunteering; Covid-19; Québec; Registered charities; Essential services / Bénévolat; Covid19; Québec; organisme de bienfaisance; services essentiels

\section{INTRODUCTION}

The COVID-19 pandemic has had a dramatic impact on work, labour markets, and organizational life across Canada. Researchers in Québec have examined the effects of COVID-19 on healthcare workers (Dubé, Hamel, Rochette, Dionne, 


\section{Alalouf-Hall \& Grant-Poitras (2021)}

Tessier, Pelletier, \& Institut national de santé publique du Québec, 2020); changes in working conditions, notably in relation to telecommuting (Saba \& Cachat-Rosset, 2020; Tremblay, 2020); and on the evolution of the labour market in a broader sense (Castro, Lange, \& Poschke, 2020). While these insights and analyses are certainly significant, the vast majority of them deal with one particular form of work: remunerated or paid work. These studies leave aside unpaid or volunteer work, which are essential to the functioning of Canadian society, particularly in times of social and economic crisis. This article addresses this research gap by exploring the impact of COVID-19 on the economic, social, and political function of volunteer activity in Québec. Moreover, it explores how the COVID-19 crisis has reworked the meanings and practices of solidarity, mutual aid, and generosity within the Québec voluntary sector and the subsequent impacts on volunteer resource management.

In 2018, 12.7 million people living in Canada (41\% of those 15 or older) volunteered for charitable organizations, nonprofit organizations, or community organizations (formal volunteering). They contributed 1.7 billion hours, the equivalent of 863,000 full-time-equivalent jobs (Hahmann, du Plessis, \& Fournier-Savard, 2020). ${ }^{1}$ Apart from Canadians who volunteer formally, more than twice as many individuals aged 15 and over offer direct informal aid to persons living outside their household, such as relatives, friends, and neighbours. This world of volunteerism has been profoundly impacted by the exceptional circumstances brought on by the COVID-19 pandemic.

In a recent article, the political scientist Sylvain A. Lefèvre (2020) invites reflection on the COVID-19 pandemic beyond its economic impact, pointing out that it is "challenging the architecture of the social ties that connect us with each other, our way of 'making society"' (p. 11). ${ }^{2}$ Thinking about the changes that have taken place in the practice of volunteer activity, which is truly a "cornerstone of communitarian and mutual aid in our society" (p.12), amounts to thinking about how a core part of our social fabric reinvents itself in times of crisis and about issues of community and regional resilience.

In every region of Québec, volunteers have come forward and formed groups to aid the most vulnerable among us. This article identifies the major impacts that COVID-19 has had on the voluntary sector in Québec. Specifically, it considers the major effects of COVID-19 on the make-up of the volunteer pool for community-based organizations and how the institutional infrastructure of volunteering is being redefined, both organizationally and ideologically. This infrastructure is made up of organizations and networks of organizations that act as intermediaries between volunteers (actual and potential) and organizations working on the ground (e.g., charities, community groups, public bodies) that need volunteers to function and offer their services. COVID-19 has resulted in a dramatic reimagining of the important social, economic, and political function of formal volunteering. While volunteering was previously conceived as an instrument for addressing social needs by and for the community, COVID-19 demanded an instrumentalized volunteer sector that could serve as a crutch for a society engaged in crisis management.

\section{THEORETICAL FRAMEWORK: FORMAL VOLUNTEERING}

Volunteering is generally understood as an altruistic behaviour or act. It is thought of as giving the gift of oneself (Mattei, 2007), which can take the form of specific acts such as giving blood or giving of one's time (Archambault \& Prouteau, 2009; Prouteau \& Wolff, 2008). Furthermore, as Dan Ferrand-Bechmann (1992) notes, volunteering "is not remunerated financially, and is carried out without social constraint nor sanction for the individual who chooses not to do it" (p. 35).

Similarly, Québec and French sociologists associated with the anti-utilitarian movement in the social sciences conceive of volunteer engagement from the angle of a free and free-time donation. They attribute political significance to the voluntary act, however, because it promotes the creation of social relations based on reciprocity (Godbout, 2002; Godbout \& Caillé, 1995). As Jacques Godbout (2002) explains: 


\section{Alalouf-Hall \& Grant-Poitras (2021)}

The volunteer attaches importance to the connection more than to the product, he grants time to time. And in this sense, he is opposed to the market. The act of volunteering, free and open, to a stranger is a radical protest against market globalization, which asserts that time is only money. (p. 46)

These classical definitions, which have a certain heuristic value when it comes to studying volunteers' inherent motivations, individualize the phenomenon of volunteering while simultaneously assigning it a singular meaning. This article takes a more holistic approach, examining volunteering not as an individual gesture but as an inherently social phenomenon that occurs within an organized and politically structured sector-a sector that regulates and co-ordinates the gifts of time and labour offered by individuals - and is embedded within the society it operates in. This distinction is important. As Eric Gagnon, Andrée Fortin, Amélie-Elsa Ferland-Raymond, and Annick Mercier (2013) explain:

Volunteering, as a specific set of activities, or a specific sphere in social life, with shared goals, as recognized by policies or by discourse, with its own organizations and being subject to assessment and evaluation, is a relatively recent phenomenon. Volunteerism did not exist 100 years ago; there were activities that were characterized as volunteer or charitable, but no volunteer sector. (p. 3)

This theoretical approach helps us reflect not merely on the interpersonal dynamics volunteering gives rise to but more generally on the social functions assumed by this form of commitment with regard to the production and reproduction of society. Such a posture implies being attentive to the fact that volunteering is "a reality in motion" (Thibault, Fortier, \& Albertus, 2007, p. 7), and that its meanings and fields of action change over time and space (Gagnon \& Fortin, 2002 ; Gagnon \& Sévigny, 2000). In doing so, the socio-demographic, political, and cultural realities that constitute voluntary activity are subject to change as transformations or crises occur within society.

This study is motivated by the following question: in the Québec context, how does the social phenomenon of volunteering change in the face of crisis?

In the pre-COVID Québec context, volunteer action served two primary functions. First, the work of volunteers made it possible to significantly increase the number and extent of services available within a given community, particularly for disadvantaged populations or those with special needs (e.g., the elderly, people with disabilities, and people experiencing homelessness). These services meet material and social needs that, for various reasons, are not supported by state actors or private companies. Volunteering is, therefore, considered to play an active role in "social development" (PanetRaymond, Rouffignat, \& Dubois, 2002), a role that is explicitly recognized by the Québec government through its Government Volunteer Action Strategy 2016-2022 (Government of Québec, 2016). This notion of social development emphasizes how the production of services by volunteers goes hand in hand with the production of social links. As André Thibault, Julie Fortier, and Patrice Albertus (2007) explain:

Reporting on volunteering is not just about reporting on its output or functionality as a "workforce" providing services, hours, skills, etc. It is also about creating links and bridges between people who affect both "beneficiaries" and volunteers. (p. 13)

This view of volunteerism is in line with the United Nations' State of the World's Volunteerism Report 2011, which argues that volunteering "benefits both the whole of society and the person who volunteers by reinforcing confidence, solidarity and reciprocity among citizens and purposefully creating opportunities for participation" (Leigh, 2011, p. b). Volunteerism has for decades been considered a lever for social and community development (Peter \& Sue, 2015). Indeed, for JeanMichel Peter and Roger Sue (2015), volunteering has a direct impact on communities since it develops social connections and cohesion among individuals. This is also the case with the redefinition of the role of the state and its progressive disengagement from several areas of social action via austerity measures, the marketization of social services, and general processes of neoliberal restructuring. 


\section{Alalouf-Hall \& Grant-Poitras (2021)}

The second primary function served by voluntary action also fuels and empowers social and community life. In addition to providing services and strengthening the social capital of communities (Putnam, 2000), volunteering increases individuals' "power to act socially" (Olin Wright, 2020, p. 160). Within modern volunteering, or what Belhassen Redjeb (2008) calls "neo-volunteering," volunteering is experienced and thought of as civic engagement and "thus constitutes an expression of a democratic and healthy society" (p. 74). This is particularly true for certain segments of the population in which voluntary work is seen as a means of integrating into the wider social structure in a socially useful way. This is the case with former prisoners or the elderly, for example. Retirement is sometimes synonymous with exclusion from working life, and becoming a volunteer offers a means to continue contributing to society or get involved in associations that take positions on collective issues that concern and challenge them (Carette \& Lamont, 1988).

To accomplish these functions of social development and empowerment, volunteering has been institutionalized and professionalized in recent years (Redjeb, 2008; Tardif Bourgoin, 2013). The mobilization, organization, and reproduction of the volunteer work force is supported and supervised by organizations and associations that call on managerial expertise. Volunteering cannot, therefore, be reduced to the sum of individual donations of time; it also depends on an institutional framework that ensures it is deployed in a coherent way in society. In this way, Gagnon et al. (2013) urge us to view voluntary action as

an institution that generates or supports these actions and gives them a place and legitimacy within society; a set of federation and associations, of government policies and programs, of similar discourse and goals, which regulate these actions, and give volunteers a common identity and similar experience. (p. 203)

In espousing a perspective that conceptualizes volunteering as an institutionalized sphere of activity-albeit one that is constantly evolving - it is necessary to make the distinction between formal volunteering (within a framework) and informal volunteering. Individuals who engage in formal volunteering provide services to others without remuneration through a group or organization at least once during a given year (Hall, Knighton, Reed, Bussière, McRae, \& Bowen, 1998). Here, the voluntary sector or volunteer activity refer to this type of volunteering, in the sense that there is organizational mediation between the gift of time and labour and the beneficiaries of that gift. Informal volunteers, on the other hand, provide assistance of their own initiative, either directly to a person outside of their household or indirectly to a collectivity or in a particular setting, without a group or organization serving as intermediary (Duchesne, 1989). Family caregivers fall into this second category. While this latter form of volunteering has played an important role in maintaining communities' resilience during the COVID-19 crisis, this analysis is limited to formal volunteering.

\section{METHODOLOGY}

The methodological approach draws on triangulated sociological methods, such as semi-structured interviews, field observations, and document analysis. It seeks to document and understand a range of experiences and perspectives within and across various Québec voluntary sector organizations during the pandemic.

\section{Field data collection}

This article draws on two distinct forms of qualitative data (semi-structured interviews and field notes recorded during organizational webinars). First, from March 2020 to January 2021, semi-structured interviews were carried out with four individuals from four charitable organizations, each lasting approximately two hours. Two of these organizations-Paroles d'excluEs and the Welcome Hall Mission-have a pool of volunteers working on the ground, while the other two-the Fédération des centres d'action bénévole du Québec (FCABQ) and the Réseau de l'action bénévole du Québec (RABQ) focus on promoting volunteer activity in Québec. These organizations were selected for the boldness and drive they displayed during the first two waves of the pandemic. The first group works in community philanthropy and alongside Québec's social services sector. The second group specializes in the management of volunteers and played a key role in the government's appeal for volunteers at the start of the pandemic. 


\section{Alalouf-Hall \& Grant-Poitras (2021)}

Second, two webinars organized by Québec-based philanthropic organizations, focusing on volunteering in a pandemicRecruiting for the Red Cross. What Are the needs in a Pandemic on May 7, 2020, co-organized by the Canadian Red Cross and Université du Québec à Montréal, and COVID-19, Montréal-North and Philanthropic Response in Québec on May 28, 2020, presented by Philanthropic Foundations Canada (PFC)—served as primary data sources. These webinars represent four hours of discussions with more than ten different organizations in Québec, as well as government officials, such as the mayor of the borough of Montréal-Nord and sector leaders from the Table de quartier de Montréal Nord, Centraide of Greater Montréal, and the Canadian Red Cross. Participants discussed a range of topics related to COVID-19, ranging from organizational challenges to volunteering needs. These webinars generated approximately ten pages of field notes.

Together, the interview data and webinar-based field data provide a nuanced illustration of the Québec volunteer sector's response to the COVID-19 pandemic. Interviews and webinar questions focused on topics such as how organizations operate during COVID-19, volunteering and volunteer resource management, and their contributions to local public welfare.

\section{Documentary research}

An in-depth analysis of organizational documents from the four aforementioned Québec-based charitable organizations was carried out, with a specific emphasis on organizational press releases (FCABQ, 2020a, 2020b, 2020c; RABQ, 2018, 2020a; Parole d'ExcluEs, 2020a). In total, 16 documents were selected for in-depth coding based on the following inclusion criteria: "volunteering in Montréal (or Québec)," "COVID-19," "community philanthropy," and "emergency solidarity." The final data set included mission statements, strategic plans (RABQ, 2020b; Welcome Hall Mission, 2020), program descriptions (Paroles d'ExcluEs, 2020b), newsletters, and social media posts (such as Twitter and Facebook) from the four main organizations dating back to the beginning of the pandemic.

\section{Data analysis}

Interviews were transcribed in their entirety and then coded according to a pre-established analysis grid (Comeau, 2000). Inductive coding of the documents began by focusing on the obvious content of the interviews (Miles \& Huberman, 2003). Manual colour coding enabled the easy identification of major themes within the field data. These first order codes were grouped around the following categories: economic functions (the provision of services); social functions (the production of interpersonal links); and political functions (the development of citizenship). Second, a thematic content analysis was conducted to systematically study the relationship, interdependence, and interaction between the policies and practices developed by the selected case study organizations and the organizations that participated in the webinars. Third, themes were revised based on similarities and areas of tension. This yielded the following three topics: the background or context of volunteer activity and responses during the first lockdown; the integration and retention of volunteers through new policies and programs; and the institutionalization of a health-centric rationality in the structuring of volunteer work.

\section{Results}

The section presents the results of the fieldwork. They are organized into three stages: the impact of the first lockdown on volunteer activity in Québec; the integration and retention of volunteers through new policies and program; and the institutionalization of a health-centric rationality in the structuring of volunteer work. By presenting these results chronologically, it is possible to follow the metamorphosis of the sector during the crisis, starting with how the volunteer pool suddenly changed with confinement and social distancing through to the redefinition of the modalities of volunteer management implemented by the organizations.

\section{The background or context of volunteer activity and responses during the first lockdown}

As with all spheres of activity in Québec society, the volunteer sector was turned upside down on March 13, 2020, the 


\section{Alalouf-Hall \& Grant-Poitras (2021)}

day the Québec government declared a health emergency and imposed a total lockdown in the province. The shock waves that hit Québec's economic and social life also immediately impacted the pool of available volunteers, which was suddenly significantly diminished. This was due to the fact that seniors, a group especially vulnerable to the effects of the SARS-CoV-2 virus, are the most active in formal volunteering. As noted by Tara Hahmann, Valerie du Plessis, and Patric Fournier-Savard (2020), in 2018, individuals from the Silent Generation (40\%) and Baby Boomers (31\%) were more likely than those of the Internet Generation (18\%) to be among those considered primary volunteers by having devoted 132 hours or more to volunteer activity. ${ }^{3}$ Volunteer numbers and hours declined for three out of five charities during COVID-19 (Lasby, 2021).

Out of concern for their safety, most organizations advised their volunteers aged 70 and older to stay home, in accordance with public health directives. For Québec's Centres d'actions bénévoles (CABs) (volunteer action centres), this resulted in a loss of about 80 percent of their volunteer pool during the first wave of the pandemic.

Some sectors of the economy had to shut down their activity to help slow the spread of the virus. In these sectors, considered "non-essential," all volunteer activity had to pause. The culture and leisure sectors were the hardest hit by these constraints, leisure being, by far, the sector that attracts the largest percentage of volunteers. In 2018, 37 percent of Québec volunteers reported having been involved with organizations in this sector (Fournier, 2018). In short, a very significant number of volunteers found themselves in a work stoppage, thereby instantly losing the many benefits they gleaned from this type of involvement in society.

The magnitude of the impact of the lockdown on volunteer activity should not be underestimated: CABs put a stop to 93 percent of the 80 services that are generally widely offered to the public. Only three major CAB services were declared essential when the health crisis took hold: the home delivery of meals, friendly visits, and transport and accompaniment. Thus, the volunteer sector was mainly called upon to intervene in services that aimed to protect the most vulnerable and, a fortiori, the elderly. As one representative from the Montréal-based Welcome Hall Mission points out:

Welcome Hall Mission offers essential housing services in several areas in Montréal but also emergency food aid for the most vulnerable individuals. When the pandemic hit, we had to adjust rapidly to not leave anyone in dire straits. We started up new services, which we were able to provide thanks to our volunteers, like the home delivery of food baskets. As well, the government contacted us to ask us to put in place additional shelters in the downtown area, such as the one that was set up in the Place Dupuis Hotel for homeless individuals. ${ }^{4}$

In this difficult situation, the challenge became to find and mobilize volunteers who could ensure the provision of the three aforementioned essential services: meal delivery, friendly visits, and transport and accompaniment. It became urgent to replace the elderly in the volunteer pool while ensuring their basic needs were met. To do that, public authorities put out a call asking all individuals who were healthy, under 70 years of age, and had some spare time to offer their time to organizations that were now lacking resources. On March 26, 2020, at a press conference organized by the government of Québec and public health authorities, ${ }^{5}$ Premier François Legault and Jean Boulet, minister of Labour, Employment and Social Solidarity, called on the public to show its solidarity by signing up with volunteer banks. On the recommendation of the RABQ, the government's privileged partner in matters of volunteer activity, individuals interested in volunteering were invited to submit applications via Je Bénévole, a virtual matching platform managed by the FCABQ.

The population of Québec responded very positively to this appeal. In the two weeks following the press conferencefrom March 26 to April 14-more than 20,000 people registered. "From that moment on," explains the FCABQ's director, "we saw a complete reversal in volunteering trends: the pool of candidates for volunteering was now too large relative to available opportunities. We had never seen that before." 


\section{Alalouf-Hall \& Grant-Poitras (2021)}

Given that the health-related restrictions mostly applied to older people and because individuals who had been forced into unemployment suddenly saw their schedules free up, efforts to solicit help did not necessarily connect with the same public as usual. A Welcome Hall Mission representative puts it this way: "Our seniors gradually stopped volunteering, and new volunteers appeared subsequent to the government's appeal. Mostly students, and salaried employees whose businesses had shut down."

According to the FCABQ's director, the dominant age group accessing Je Bénévole in this first wave were neither the oldest (the Baby Boomers) nor the youngest (Generation $Y)^{6}$ but rather those between 40 and 60 years of age-in other words, Generation Xers. According to a participant from the COVID-19, Montréal-North and Philanthropic Response in Québec webinar, "For some young people, it was a good time to start volunteering. The crisis only reinforced their desire to act."

When organizations had to close during the first lockdown in March 2020, spontaneous initiatives propelled by volunteers sprang up in certain neighbourhoods where community-based philanthropy and solidarity were already strong. These types of bottom-up initiatives aimed to make up for the temporary absence of groups that were transitioning toward telecommuting. For instance, Welcome Hall Mission was able to develop a new delivery service-which did not exist prior to the pandemic - thanks to the unwavering commitment of volunteers. This new initiative has brought about an improvement in the organization's level of service, a change that Welcome Hall Mission hopes to maintain in the years to come to help the elderly as well as persons suffering from serious illness. The same phenomenon of bottom-up volunteer-based organizing was observed at Paroles d'excluEs, a Montréal-based charity that combats poverty and social exclusion:

This new group spontaneously, and very rapidly, established a chain of solidarity, initially based on communication by phone. People would call each other to check in, to make sure that all was going well, despite the circumstances. Then, we started to see "clandestine" exchanges of food, based on each person's needs. A can of peas for a can of baked beans and so on. At the same time, a small group of citizens formed to take care of errands for others who could not leave their homes. Manon and Céline L. on that team stored food at their home since we could not open our office. Céline B and Guy were constantly coming and going; they took some risks by doing errands and making deliveries even though we didn't yet have protective equipment (masks, gloves, face shields) for them. And all this came about in a week!

Managing volunteers in a pandemic presented the sector with a dual challenge: new volunteers had to be integrated rapidly, yet organizations had to make sure all these people could work without compromising their safety, the safety of their families, and the safety of the organization's clients.

\section{The integration and retention of volunteers in a pandemic}

The CABs' priority was to match new candidates with organizations in need. Many candidates were indeed recruited; however, the new pool of volunteers was simply too large relative to sector's capacity to integrate them. As the FCABQ's director notes:

CABs normally do have the resources needed to be able to give volunteers the structure they need, but the influx from March 26 and April 14 was simply too big — contacting and placing the 20,000 people who registered in two weeks was beyond our organizational capacity. For the $C A B$, managing the volunteer bank generated by Je Bénévole, orienting the people who contacted us wanting to get involved, etc., took up a lot of time and really made a dent in our resources.

That said, the number of individuals integrated into the voluntary sector is substantial. From the time of the government's appeal on March 26 until the end of 2020, about 40,000 applications were submitted to Je Bénévole. Roughly half of the applicants were accepted and integrated into the sector. The processing of the applications generated a paradoxical situation: volunteers had to be recruited and mobilized to meet urgent needs, but organizations that needed them still had 


\section{Alalouf-Hall \& Grant-Poitras (2021)}

to carefully analyze their files to retain the most qualified individuals for the open positions. A major issue arose with regards to the verification of candidates' criminal records, which is a mandatory procedure in sectors where volunteers are working with vulnerable populations. The police are responsible for carrying out these checks, but verifications were not always done within a reasonable timeframe and some recruitment efforts were blocked. The RABQ's director explained that in some instances she had to intervene with the Ministère de la sécurité publique to get the police department involved to speed up the verification process.

In the long term, the issue for this sector will be retaining these new volunteers. "Our challenge is going to be to keep these people volunteering," explains the RABQ's director. "For some of them, it's probably the first time that they have even thought of giving their time because they had a lot of time on their hands all of a sudden-they either went on unemployment or were receiving CERB". ${ }^{7}$ Those in charge at FCABQ and Welcome Hall Mission agree. For the FCABQ's director, the big challenge will be keeping new recruits mobilized to meet the many needs that remain when the pandemic is over.

The Welcome Hall Mission is certain that some of these new recruits will continue to be active in 2021. However, some doubt remains regarding students and individuals who are between jobs as a direct consequence of the health crisis. As a result, many in the sector are engaged in serious reflection on how to rethink the terms and conditions of engagement so that volunteering can stay compatible with the regular schedules of workers and students. Otherwise, the return to "normalcy" might well translate into the complete disengagement of the volunteer pool. The director of the FCABQ notes:

We have to adjust our way of organizing volunteering. We have seen that it is possible to attract more than 30,000 candidacies since many people are not working. But we also know that several organizations offer volunteers time slots within the Monday-to-Friday, nine-to-five timeframe. The crisis has shown us that this type of scheduling does not really line up with the availability of people who work. We have less of the kind of volunteer who comes week after week, and that was happening even prior to the crisis. We, therefore, have to adjust our offer and demonstrate more flexibility in order to adapt to the realities of different kinds of volunteers.

When it comes to the volunteers who had to temporarily stop their volunteer activities, the challenge will be to make sure that the current crisis does not result in their demobilization. This challenge is currently generating a fair amount of anxiety, especially in the sports, culture, and recreation sectors. These are the spheres of activity that have suffered the most from the lockdown and social distancing measures. The return to service of volunteers will be a key condition of charitable organizations being able to resume their activities once organizations in the sports, culture, and recreation sectors are allowed to reopen.

Among those making proposals regarding the reintegration of these volunteers, some are speaking out to say that the category of volunteer activity considered "essential" needs to be broadened. For example, the Conseil québécois du loisir, an RABQ member, recently published an open letter as part of an awareness campaign called Le loisir, un service essentiel in which it asks that leisure be considered an essential service. To quote the conseil: "its benefits (those of recreational activity) are well known when it comes to preventive health, but it also has educational value, serves as a cultural vector, and promotes social inclusion for young people, seniors, and disabled individuals" (Conseil québécois du loisir, 2020).

Both the RABQ and the FCABQ support this position and argue that the essential character of volunteer work in fields such as recreation should be recognized. There should, as well, be a general acknowledgement of the fact that volunteering is a vector for social integration. In this vein, the FCABQ makes the case for allowing older volunteers to resume their involvement. "During a lengthy period of time, the government said that people over 70 could not engage in volunteer work," explains the federation's director. "On our end, we frequently went back to the government on that point, because volunteers aged 70 and over want to start volunteering again. For them, volunteering is on a fundamental level an activity that does them good." 


\section{Alalouf-Hall \& Grant-Poitras (2021)}

\section{Health-centric rationality in the structuring of volunteer work}

After the integration of new volunteers, the sector's second major challenge was to structure volunteer work in a way that would allow volunteers to offer essential services in a safe environment and without too many complications. The continuation of services offered by volunteers came with a price, a health-centric rationality that radically transformed the day-to-day experience associated with this kind of social involvement. These adjustments to the structuring of volunteer work to deal with the risk of contamination happened on four levels.

First, organizations had to completely rethink the usage of their facilities. From the start of the first wave of the pandemic, they closed off access to their facilities to prevent any outbreaks. This measure created both logistical and social problems. Logistically, it made it more difficult to carry out activities that normally occur indoors, such as meetings or assemblies. In the case of CABs, for example, their facilities often include kitchens where meals for meals-on-wheels are prepared. In order to respect social distancing measures, cooks had to prepare meals by themselves, without help from volunteers. But on a deeper human level, the closure of organizational facilities hindered volunteer socialization. As one Paroles d'excluEs representative explains:

You have to understand that our two sites are meeting places and spaces for sharing where people can bring forward ideas and propose projects, though they are not just that. They are also spaces that help break down social isolation. Unfortunately, on March 13 we had to close our premises. ... Still, despite the challenges presented by the lockdown, Parole d'excluEs was able to continue to reach the most vulnerable individuals, thanks to the support of very committed citizens [this organization refers to its volunteers as citizens].... These individuals are our "eyes and ears" on the ground; they are essential.

This can be said of all CABs, which serve as spaces for volunteers to meet and socialize with each other and staff.

Second, organizations took on the task of redeploying services virtually where possible. Tele-volunteering became the method of choice for several types of services. To take one example, CABs generally provide friendly visits to the elderly. These drop-ins help break down social isolation. They also offer the chance to make sure that the senior's needs are taken care of and, when necessary, provide an opportunity to refer them to relevant organizations. Given the importance of these drop-in visits to seniors' well-being, the decision was made to reimagine these visits as "friendly calls." Numerous volunteers were mobilized to make support calls and keep the lines of communication with vulnerable groups open and stay attuned to their needs. However, as our Parole d'excluEs representative points out:

During the pandemic, I saw people give up their phone service for financial reasons. Their isolation becomes even more acute! How can you have exchanges with other people, get news, and, of course, get the information you need? This is a major issue.

Third, for services that had to be offered in person, there was a need to make protective equipment available to reduce the risk of contamination. Organizations absolutely did not want new volunteers to be vectors for spreading the virus. An initial problem during the first wave of the pandemic was the scarcity of personal protective equipment, such as specialized masks. Additionally, organizations had to ensure that volunteers received the proper training, the nature of which varied according to the working environment. Training was needed not only on a professional level but also for the hygiene measures. For meals-on-wheels deliveries, for instance, volunteers were directed to leave the meals on a porch or stoop to avoid contact with recipients. But what was gained in terms of safety was lost in terms of the quality of person-to-person interaction, which is often an integral part of the aid that volunteers provide. Here is how the director of the FCABQ puts it:

Yes, there is the delivery of a meal, but there is also everything associated with it. In other words, checking in with the elderly individual, who is often alone and vulnerable, and making sure they are alright. It is often during the delivery activity that volunteers detect other problems going on with the older person. They can then refer them to other services. With the pandemic, that kind of extra step was not possible. 


\section{Alalouf-Hall \& Grant-Poitras (2021)}

The fourth and final challenge was for organizations to take charge of and see to the well-being of their volunteers. That well-being was severely tested by the anxiety-provoking climate and the health measures that had been imposed, which negatively impacted the quality of volunteer engagement. In that vein, organizations such as Paroles d'excluEs saw to it that their members could receive psychological support following the first wave of the pandemic. "At that point, morale was pretty low, so we made more psychological support available," the representative reports. "We organized a workshop, 'How to Come out of Lockdown in a Healthy Way?' We also offered online group sessions with a psychologist."

On top of offering direct support to volunteers, organizations also spoke out publicly to denounce the conditions volunteers had to work in. The FCABQ's director drew a lot of attention in the media with his criticism of the fact that, in many regions of Québec, volunteers providing transport could not go inside a hospital with beneficiaries and had to spend several hours waiting in their cars (Porter, 2020). The FCABQ urged the authorities to rapidly arrange for waiting areas in hospitals to accommodate volunteers to avoid discouraging them from offering this vital form of assistance. In short, on many levels, the sector made an effort to lessen any complications and inconveniences caused by health measures that might impair the work of volunteers.

\section{DISCUSSION}

As we indicated in the theoretical framework, formal volunteering serves three main functions in society: an economic function, because it provides free labour that increases the supply of services to society thus contributing to community development (Panet-Raymond, Rouffignat, \& Dubois, 2002); a social function, because volunteer involvement produces bonds of solidarity (Godbout, 2002; Godbout \& Caillé, 1995); and a political function, because volunteer involvement serves as a means for certain individuals or groups to gain recognition in the public arena while simultaneously developing their power to act (Carette \& Lamont, 1988; Redjeb, 2008). How should the changes in volunteering in Québec amid the COVID-19 pandemic be qualified? How has volunteering restructured itself to maintain or redefine the three major functions through which it contributes to the production and reproduction of the "collective architecture of solidarities" (Lefèvre, 2020, online).

In classifying and interpreting the meaning of this study data along these constitutive dimensions of volunteering, volunteering still performed economic, social, and political functions during COVID-19, but the meaning and purpose of these functions were quite different. This research shows that in the context of this health crisis, an entirely new politico-managerial rationale emerged, sparked by urgency and the necessity to meet the basic needs of vulnerable populations. A new societal configuration emerged, in which voluntary action is institutionally and politically framed to carry out its fundamental functions differently.

\section{Social and economic functions}

The economic and social functions of volunteering are often seen as inseparable, as the production of social ties are intimately linked to the provision of services. It is interesting to observe, however, that this shift in the purposes of voluntary action was done at the expense of the social dimension that is intrinsic to it. First, with regard to the sector's social development function, study results show that health constraints often had the effect of sacrificing spaces and moments typically dedicated to the creation of social relations that spill over to benefit service delivery. During COVID-19, volunteers were not allowed to meet and socialize with each other on agency premises, and physical distancing measures affected the quality of the relationships they had with their beneficiaries. By thus prioritizing the economic over the social, volunteer work has moved away from the logic of giving that gives it meaning (Godbout, 2002). Nevertheless, setting of tele-volunteering has made it possible, to some extent, to pursue certain activities focused on the production of social links for populations who suffer from isolation or require psychological support. What was more prominent on this social level, 


\section{Alalouf-Hall \& Grant-Poitras (2021)}

however, was the role of the sector in supporting community and societal resilience in times of crisis. Thus, when registered charities closed their premises while transitioning into the first lockdown, volunteers gave their time to intervene in neighbourhoods as key local actors. They were indispensable players in strengthening resilience in their communities and across the province. Ultimately, their contribution was more about maintaining social cohesion-with the aim to provide essential services to as many people as possible —-than about generating interpersonal relationships among volunteers and between volunteers and beneficiaries.

\section{Political function}

With regard to the volunteer sector's political function of empowering individuals, the demarcation of voluntary activities to so-called essential services has been done at the sacrifice of a large number of voluntary activities promoting participation to public and cultural life. As observers who recall that the parliamentary process have been paralyzed (Descoteaux, Néméh-Nombré, \& Pierre, 2021), it should be remembered that the state of emergency has also affected the democratic life on the ground in associations, advocacy or interest groups, and social movements. While volunteering normally constitutes the cornerstone of a healthy associative democracy, in the context of a health crisis, it took on more of the appearance of a civic duty ordered by the state than a true manifestation of citizenship (Redjeb, 1991).

In sum, volunteering was previously conceived of as an instrument for addressing social needs by and for the community -in other words, as a means of social and political action independent of the state. With the COVID-19 pandemic, the work of old and new volunteers was instead instrumentalized because of the regulations put in place, thus returning voluntary action to the role of a crutch for a public sector engulfed in crisis management. To briefly illustrate the shift from one logic of voluntary action to another in the face of the crisis, Figure 1 compares the economic, social, and political functions of voluntary action as pursued before the pandemic and during the first months of the pandemic.

\section{Figure 1: The economic, social, and political functions of formal volunteering before the} pandemic versus during the pandemic (first and second wave)

\begin{tabular}{|l|l|l|}
\hline & Formal volunteering beforeCOVID-19 & Formal volunteering duringCOVID-19 \\
\hline $\begin{array}{l}\text { Economic } \\
\text { function }\end{array}$ & $\begin{array}{l}\text { Contribution of volunteers in all } \\
\text { spheres of activity of the company. }\end{array}$ & $\begin{array}{l}\text { Limitation of volunteer activities to } \\
\text { services declared essential by the state. }\end{array}$ \\
\hline $\begin{array}{l}\text { Social } \\
\text { function }\end{array}$ & $\begin{array}{l}\text { Creation of social links between } \\
\text { volunteers, and between volunteers } \\
\text { and service recipients. }\end{array}$ & $\begin{array}{l}\text { Strengthening the resilience of } \\
\text { populations most affected by the effects } \\
\text { of the crisis. }\end{array}$ \\
\hline $\begin{array}{l}\text { Political } \\
\text { function }\end{array}$ & $\begin{array}{l}\text { Promotes the vitality of democratic life } \\
\text { and the recognition of individuals or } \\
\text { groups in the public space. }\end{array}$ & $\begin{array}{l}\text { Takes the form of a citizen's duty to ac- } \\
\text { company the public sector in its manage- } \\
\text { ment of the crisis. }\end{array}$ \\
\hline
\end{tabular}

While the crisis shows an increase in the complexity of the aims of voluntary action, the cohabitation of its traditional functions with this new function is not self-evident-the latter can encroach on the former. In future crises, would it be possible to think collectively about a better conciliation between the imperatives of the present (the resilience function of volunteering) and the importance of preserving social ties and the political requirements of a society that wants to be democratic?

Although still exploratory, this research helps assess the main institutional changes that have occurred in voluntary action. The analysis reveals that volunteering is a dynamic institution with interventions can be deployed in various ways to respond to novel needs generated by a crisis. At a more micro-sociological level, however, this analysis does not make it possible to make claims regarding the range of motivations that led so many individuals to volunteer in organizations 


\section{Alalouf-Hall \& Grant-Poitras (2021)}

when the risk of illness was significant, nor does it reveal the meaning that volunteers gave to their commitment to volunteering as it evolved during the pandemic. Future research on the voluntary sector during COVID-19 should pursue these lines of study. Such research would enrich these results and be very useful for the sector-especially for managers who face significant challenges in terms of soliciting and retaining volunteers.

\section{CONCLUSION}

As COVID-19 will not be the last crisis, it is necessary to be conscious of the fact that volunteers will be playing an increasingly important role in disaster risk reduction, disaster management, and, more broadly, humanitarian emergencies (McLennan, Whittaker, \& Handmer, 2016). Discussions focused on this kind of episodic volunteering during the pandemic (both the first and second waves) have brought several notions to the forefront.

First, there is a need to be able to quickly activate a pool of competent volunteers. Governments, community groups, and registered charities must work together to determine how to mobilize them in a formal framework that is safe. However, registered charities and the community sector desperately need increased funding to achieve this and to support community-based projects. These latter projects are often conceived by volunteers, who frequently have a more fine-grained perspective on solutions that is shaped by community-specific knowledge and established social ties and relationships.

At the core of community-based work is a diversity of community organizations and volunteers offering a variety of services, including helping persons experiencing homelessness; distributing food baskets; providing services to individuals with mental health issues; and helping to keep shelters open for women who are victims of violence. It is urgent to keep moving ahead on the recognition of volunteer work as an essential service and an indispensable factor in community resilience, particularly in times of crisis. Many strategies are possible. For example, employers and universities could be incentivized to create conditions favourable to volunteerism as is already the case, to some extent, in Québec schools. ${ }^{8}$ Similarly, government could create more honours and awards for volunteer service. ${ }^{9}$ Above all, however, governments and philanthropic funders (such as grantmaking foundations) must rethink their strategies for allocating funds to maximize liquidity for frontline organizations.

The pandemic has revealed that Québec is home to a mature voluntary sector, capable of rapidly mobilizing and organizing a large and cost-free labour force for a long period of time (10 months of pandemic). The challenges that the sector faces as a result of COVID-19 are not necessarily new; rather, they were already part of a pre-pandemic landscape where there was a dearth of fundamental responses to major issues, such as access to food and healthcare, economic challenges concentrated in areas such as Montréal North, the fight to reduce the digital divide, and the reworking of the public income security to implement a decent guaranteed minimum income.

\section{Notes}

1. There has been a slight decline since 2010. According to Statistics Canada, 13.3 million people, $47 \%$ of Canadians 15 years and over, volunteered in 2010 . That represents about 2.07 billion hours, the equivalent of slightly fewer than 1.1 million full-time jobs (Vézina \& Crompton, 2012).

2. This has been translated by the authors.

3. The Silent Generation is generally defined as people born from 1928 to 1945 (from 75 to 92 years old). The Baby Boomers generation is generally defined as people born from 1946 to 1964 (from 56 to 74 years old). The Internet Generation includes Generation Y, also called the Millennials (born 1980 to the late 1990s) and Generation Z (born in the early 2000s and on).

4. All the interviews were conducted in French; they have been translated by the authors. 


\section{Alalouf-Hall \& Grant-Poitras (2021)}

5. The Québec government's daily press conferences drew a huge audience. La Presse's numbers show that: "between March 13 and May 4, an average of 2.1 million Québecers listened in on the Legault-Arruda-McCann interventions between 1 and 1:30 p.m" (Marquis, 2020, para. 2).

6. Engagement on the part of students and young workers should not be underestimated. With the closing of postsecondary schools and many businesses, Hahmann et al. (2020) observed increased participation among this age group: "While those in Generation Internet were less likely than others to be among the main volunteers, they did participate in a significant way in formal volunteer activity at the start of the pandemic" (p. 5).

7. The Canadian Emergency Relief Benefit (CERB) provided financial aid to employees and independent Canadian workers who were directly affected by COVID-19. Those eligible received a payment of $\$ 2,000$ for a four-week period (the equivalent of $\$ 500$ per week) between March 15 and September 26, 2020 (Canada, n.d.).

8. The Strategie d'action jeunesse 2006-2009, renewed for 2009-2014, states that "recognition and rewarding of citizen participation, and the creation of spaces for sharing, create the right conditions for volunteering to become contagious" (Gouvernement du Québec, 2009, p. 49). The strategy acknowledges the importance of encouraging youth to volunteer in their day-to-day environments. The Ministère de l'Éducation, du Loisir et du Sport committed to developing a framework for recognizing students' involvement in volunteer activity.

9. There is currently a Prix Hommage-Bénévolat Québec. According to the Ministère du Travail, de l'Emploi et de la Solidarité sociale, this honour, awarded by the government of Québec, highlights the extraordinary commitment of volunteers and organizations across the province who make a real difference in their communities.

\section{ACKOWLEDGEMENTS}

The authors thank Adam Saifer, Jean-Marc Fontan, and the anonymous reviewers for their remarks and comments.

\section{WEBSITES}

Canadian Red Cross, https://www.redcross.ca/

Centraide of Greater Montréal, https://www.centraide-mtl.org/en/

Fédération des centres d'action bénévole du Québec, https://www.fcabq.org/

Je Bénévole, https://www.jebenevole.ca/

Paroles d'excluEs, http://www.parole-dexclues.ca/

Réseau de l'action bénévole du Québec, https://www.rabq.ca/

Welcome Hall Mission, https://welcomehallmission.com/

\section{REFERENCES}

Archambault, E., \& Prouteau, L. (2009). Mesurer le benevolat pour en ameliorer la connaissance et satisfaire a une recommandation internationale. Revue internationale de l'economie sociale, 314(9), 84-104.

Canada. (n.d.). Canada Emergency Response Benefit with CRA. Ottawa, CA: Canada Revenue Agency. URL: https://www.canada.ca/en/revenue-agency/services/benefits/apply-for-cerb-with-cra.html [October 21, 2021].

Carette, J., \& Lamont, S. (1988). À propos des pouvoirs gris. Nouvelles pratiques sociales, 1(1), 133-142.

Castro, R.L., Lange F., \& Poschke, M. (2020). Trajectoires possibles du marché du travail québécois suite à la crise de la Covid-19. Montréal, QC : McGill University. Proposition à l'intention du Ministère des Finances.

Comeau, Y. (2000). Grille de collecte et de catégorisation pour l'étude d'activités de l'économie sociale et solidaire. Montréal, QC: Cahiers du CRISES ET9605.

Conseil québécois du loisir. (2020). Le loisir : un service essentiel. Drummondville, L'Express, URL: https://www.journal express.ca/2020/12/08/le-loisir-un-service-essentiel-tribune-libre/ (accessed on October 21, 2021). 


\section{Alalouf-Hall \& Grant-Poitras (2021)}

Descoteaux, C., Néméh-Nombré, P., \& Pierre, A. (2021, June 13). Il est temps de déconfiner la démocratie! La Presse. URL : https://www.lapresse.ca/debats/opinions/2021-06-13/il-est-temps-de-deconfiner-la-democratie.php [October 21, 2021].

Dubé, E., Hamel, D., Rochette, L., Dionne, M., Tessier, M., Pelletier, M., \& Institut national de santé publique du Québec. (2020). COVID-19 - Pandémie et travailleurs de la santé. Institut national de santé publique du Québec. Institut national de santé publique du Québec.

Duchesne, D. (1989). Donner sans compter: les bénévoles au Canada, Rapport analytique sur le travail no 4, cat. 71535. Ottawa, ON: Statistics Canada.

FCABQ. (2020a, April 19). Press release « Semaine de l'action bénévole 2020 ». URL : https://www.fcabq.org/news/id 179 [October 21, 2021].

FCABQ. (2020b, April, 7). Press release « COVID-19: Du soutien pour toutes les facettes de la sécurité alimentaire ». URL : https://www.fcabq.org/news/id/77 [October 21, 2021].

FCABQ. (2020c, March 26). Press release « JeBénévole.ca ». URL: https://www.fcabq.org/news/id/75 [October 21, 2021].

Ferrand Bechmann, D. (1992). Bénévolat et solidarité. Paris, FR : Syros-Alternatives.

Fournier, M. (2018). Cahier de recherche - Portrait des bénévoles et du bénévolat. Montréal, QC : Réseau de l'action bénévole du Québec.

Gagnon, É., \& Fortin, A. (2002). L'espace et le temps de l'engagement bénévole : essai de definition. Nouvelles pratiques sociales, 15(2), 66-76.

Gagnon, É., Fortin, A., Ferland-Raymond, A-E., \& Mercier, A. (2013). L'invention du bénévolat. Genèse et institution de l'action bénévole au Québec. Québec City, QC : Les Presses de l'Université Laval.

Gagnon, É., \& Sévigny, A. (2000). Permanence et mutations du monde bénévole. Recherches sociographiques, 41(3), 529-544.

Godbout, J. (2002). Le bénévolat n'est pas un produit. Nouvelles pratiques sociales, 15(2), 42-52.

Godbout, J., \& Caillé, A. (1995). L'Esprit du don. Montréal, QC: Les Éditions du Boréal.

Gouvernement du Québec. (2009). Enrichir le Québec de sa releve, Strategie d'action jeunesse 2009-2014. Québec, QC : Secrétariat de la jeunesse.

Gouvernement du Québec. (2016). Stratégie gouvernementale en action bénévole, 2016-2020. Québec, QC : Ministere du Travail, de l'Emploi et de la Solidarite sociale.

Hall, M., Knighton, T., Reed, P. Bussière, P., McRae, D. \& Bowen, P. (1998). Canadiens dévoués, Canadiens engagés : points saillants de l'Enquête nationale de 1997 sur le don, le bénévolat et la participation, no 71-542-XPF au catalogue. Ottawa, ON : Statistics Canada.

Hahmann, T., du Plessis, V., \& Fournier-Savard, P. (2020). Le bénévolat au Canada: défis et opportunités pendant la pandémie de COVID-19. Ottawa, ON : Statistics Canada.

Lasby, D. (2021). Enquête sectorielle. Les effets persistants de la pandémie de COVID-19. Toronto, ON : Imagine Canada.

Lefèvre, S. (2020). L'architecture collective des solidarités à l'épreuve de la COVID-19. Canadian Journal of Nonprofit and Social and Economy Research, 11(1), 11-15.

Leigh, R. (2011). Rapport sur la situation du volontariat dans le monde : valeurs universelles pour le bien-être. New York, NY : United Nations.

Marquis, Mélanie. (2020, May 8). Le rendez-vous de 13 h plus couru que celui de Trudeau. La Presse. URL: https:// www.lapresse.ca/covid-19/2020-05-08/le-rendez-vous-de-13-h-plus-couru-que-celui-de-trudeau [October 21, 2021].

Mattei, J. (2007). La gratuité du don de soi : Don, gratuité et bénévolat. Science \& devenir de l'homme, 54(2), 6-27.

McLennan, B., Whittaker, J., \& Handmer, J. (2016). The changing landscape of disaster volunteering: Opportunities, responses and gaps in Australia. Natural Hazards, 84(3), 2031-2048.

Miles, M.B., \& Huberman, M.A. (2003). Analyse des données qualitatives. Brussells, BE : De Boeck. 


\section{Alalouf-Hall \& Grant-Poitras (2021)}

Olin Wright, E. (2020). Utopies réelles. Paris, FR : Les Éditions La Découverte.

Panet-Raymond, J. Rouffignat, J., \& Dubois, L. (2002). Le bénévolat comme passage vers le développement social. Nouvelles pratiques sociales, 15(2), 104-119.

Parole d'ExcluEs. (2020a, March 16). Press release "Avis important — Covid-19." URL : http://www.parole-dexclues.ca lavis-important-corvid-19/ [October 21, 2021].

Parole d'ExcluEs. (2020b). Rapport d'activités 2019-2020. [October 21, 2021]. URL : http://www.parole-dexclues.ca /wp-content/uploads/2021/01/RapportPAEX2020-Final.pdf [October 21, 2021].

Peter, J.-M., \& Sue, R. (2015). La voie associative génératrice de lien social: le cas de la France. Loisir et société / Society and Leisure, 38(2), 268-238.

Porter, Isabelle. (2020, December 3). Des hôpitaux interdisent l'accès aux bénévoles. Le Devoir. URL: https://www .ledevoir.com/societe/sante/590870/hopitaux-des-benevoles-laisses-dehors [October 21, 2021].

Prouteau, L., \& Wolff, F-C. (2008). On the relational motive for volunteer work. Journal of Economic Psychology, 29(3), 314-335.

Putnam, R. (2000). Bowling alone: The collapse and revival of American community. New York, NY: Simon \& Schuster.

RABQ. (2020a, March 26). Press release "nouvelle version de jebenevole.ca." URL : https://www.rabq.ca/salle-de-presse .php?id=102\&titre=COMMUNIQUÉ\%20-\%20Nouvelle\%20version\%20de\%20Jebenevole.ca [October 21, 2021].

RABQ. (2020b). Rapport annuel 2019-2020. URL : https://www.rabq.ca/admin/incoming/20200615154349_Rapport -annuel-2019-2020.pdf [October 21, 2021].

RABQ. (2018). Le bénévolat selon les Québécois (2e version). URL : https://www.rabq.ca/rapport-perceptionbenevolat.pdf [October 21, 2021].

Redjeb, B. (1991). Du bénévolat au néo-bénévolat. Nouvelles pratiques sociales, 4(2), 59-79.

Saba, T. \& Cachat-Rosset, G. (2020). COVID-19 et télétravail : un remède universel ou une solution ponctuelle. Québec et comparaison internationale. Montréal, QC : Chaire BMO Diversité et Gouvernance, Université de Montréal.

Tardif Bourgoin, F. (2013). La formation des bénévoles : une démarche de professionnalisation ? Analyse de la mise oeuvre des dispositifs d'accompagnement et de formation des bénévoles dans trois centres sociaux parisiens. Phronesis, 2(4), 61-69.

Thibault, A. Fortier, J., \& Albertus, P. (2007). Rendre compte du mouvement bénévole au Québec créateur de liens autant que de biens. Montréal, QC : Laboratoire en loisir et vie communautaire au Réseau de l'action bénévole du Québec (RABQ).

Tremblay, D.-G. (2020). Le télétravail et le cotravail (coworking) : enjeux socioterritoriaux dans la foulée de la pandémie de COVID-19. Organisations \& territoires, 29(2), 159-162.

Vezina, M., \& Crompton, S. (2012). Le bénévolat au Canada. Ottawa, ON : Statistics Canada.

Welcome Hall Mission. (2020), Rapport Annuel 2019. URL : https://missionbonaccueil.com/wp-content/uploads /2020/06/MBA-RAPPORT-ANNUEL-2019-FR.pdf [October 21, 2021].

\section{ABOUT THE AUTHORS / LES AUTEURS}

Diane Alalouf-Hall is a PhD student at Université du Québec à Montréal. Email: alalouf.diane@uqam.ca

David Grant-Poitras is a PhD student at Université du Québec à Montréal. Email: grant-poitras.david@uqam.ca 